Volume and Issues Obtainable at Center for Sustainability Research and Consultancy

Journal of Accounting and Finance in Emerging Economies

ISSN: 2519-0318 \& ISSN (E): 2518-8488

Volume 7: Issue 4 December 2021

Journal homepage: www.publishing.globalcsrc.org/jafee

\title{
Evaluating Moderating Effect of Growth Need Intent on Relationship between Job Characteristics and Job Satisfaction amongst Garments Industry Workers in Pakistan
}

Qurat ul Ain Ahmed, PhD Scholar, School of Business and Economics, University of Management and Technology, Lahore, Pakistan

*Waheed Asghar, Director, Technical Education and Vocational Training Authority (TEVTA) Govt of Punjab, Lahore, Pakistan

Salyha Zulfiqar Ali Shah, Assistant Professor, School of Economics, Bahauddin Zakariya University, Multan, Pakistan

Muhammad Ali, FAST, School of Management, National University of Computer and Emerging Sciences

*Corresponding author's email address: director.at@tevta.gop.pk

\begin{tabular}{l}
\hline ARTICLE DETAILS \\
\hline History \\
Revised format: Nov 2021 \\
Available Online: Dec 2021 \\
\hline Keywords \\
Job characteristics Model \\
(JCM), Job Satisfaction (JS), \\
Growth need Strength (GNS), \\
Textile \& Garment Industry, \\
Production Workers \\
\hline
\end{tabular}

JEL Classification

$M 1, M 2$

\section{OPEN ACCESS}

\section{ABSTRACT}

Purpose: The purpose of this research is to analyze the correlation between the job characteristics and satisfaction among production workers in the garments sector assembly line and also to examine the moderating impact of growth need intent on both variables. The five job characteristics were employed in this research.

Design/Methodology/Approach: This research was carried out in seven garment factories in Lahore. Data has been collected from production workers of different departments; cutting, sewing, pattern making, washing, pressing, packaging, and quality checking of randomly selected factories. A structured questionnaire was used for data collection. Considering the sample size estimation, the ratio has not to be below 1:5. (Hair, Black, Babin \& Anderson, 2010) and 125 have been selected by a convenient method of sampling. Smart PLS has been used as a statistical tool for data processing and testing the hypothesis.

Findings: The research suggests two important findings. Firstly, the job characteristics significantly affect job satisfaction. Secondly, it shows that the relationship between job characteristics and satisfaction is significantly moderated by growth need intent. Implications/Originality/Value: This research will add value to the existing knowledge base and serve as a guideline for HR policymakers in the textile \& garments industry to recognize the needs for the development of their workers.

(C) 2021 The authors, under a Creative Commons AttributionNonCommercial- 4.0

Recommended citation: Ahmed, Q., Asghar, W., Shah, S. Z. A. and Ali, M. (2021). Evaluating Moderating Effect of Growth Need Intent on Relationship between Job Characteristics and Job 
Satisfaction amongst Garments Industry Workers in Pakistan. Journal of Accounting and Finance in Emerging Economies, 7 (4), 849-859.

\section{Introduction}

The success of every organization depends primarily on its employees and their feeling for their work (Ali et al., 2014). Ketchain (2003) states that employees who were satisfied with their work were stressless rather energetic and happy. He also posits that happy workers were extremely satisfied with their job because they feel secure within their organization. Human resource is the most significant among other organizational resources like capital, land, machinery equipment and materials. Manufacturing companies must have an efficient human resource that can carry out duties effectively to achieve corporate objectives. An assembly line on a production floor is an arrangement of a repetitive task assigned to an employee to attain perfection and maximum productivity (Saheed, 2018). So, manufacturing through an assembly line is a technique implemented to increase production more effectively.

Job characteristics are the aspects of work that are intended to improve internal motivation and satisfaction among employees. (Hackman \& Oldham, 1974). Research by (Hackman \& Oldham, 1976) says growth needs strength to act as an efficient moderator between several variables. Job satisfaction is defined as how ample people like or dislike their jobs (Spector, 1997). Different studies indicate a positive relationship between job characteristics and job satisfaction (Matubber \& Miah, 2001). Recent research by Yen, Yeh, \& Lin 2007 has demonstrated that work satisfaction may be considerably increased by upgrading the work model. While discussing job efficiency and employee satisfaction issues, researchers generalized motivation theories (Shanum, 2011). Hackman \& Oldham model can be used to predict whether a job redesign is possible to achieve good work and personal results (Hackman \& Oldham, 1976).

\section{Sector Background}

Historically, a country's first successful industry was its garment industry, hence gradually brought other industries to grow (Muku, 2013). The textile industry of Pakistan expanded rapidly in the late 1970s. Pakistan is Asia's eighth-largest textile exporter. Pakistani textiles are exported worldwide. The Pakistan textile industry accounts for $8.5 \%$ of GDP (TDAP, 2016). The sector also employs approximately $45 \%$ of the total workforce of the country. The textile industry of Pakistan contributes $57 \%$ to the country's exports and employs $40 \%$ of its workers (Khawar et al., 2019). The ready-made garment is a growing textile industry in Pakistan.

\section{Problem Statement}

Pakistani garment industry can be classified as labor-intensive. Mostly production-oriented factories are focused with monitoring employee output. Like other labor-intensive manufacturing sectors, textile industry too has huge wage costs (Labour Survey of Pakistan, 2016). Manufacturing employees seem monotonous in assembly line tasks and have little chance of applying their other abilities and skills (Farooqui \& Ahmed, 2013). The major purpose of this research is to investigate the job characteristics and efficacy of workers in Pakistan's garment sector, and to what extent is this model applicable to assembly line workers.

\section{Research Questions}

The current research will explore these research questions;

1. What is the relationship between job characteristics and job satisfaction in the ready-made garments sector in Lahore Pakistan?

2. Does employees' growth need intent (GNS) influence the association between job characteristics and job satisfaction in the ready-made garments sector in Lahore Pakistan? 


\section{Literature Review}

This section gives brief overview of different studies conducted in this area.

\section{Job characteristics Model (JCM)}

Hackman and Lawler first presented the job characteristics model in 1971. They established four essential job qualities in their model, namely diversity, autonomy, role identity, and feedback, however statistically, their results were not significant in quantifying the effect of job characteristics on absenteeism and turnover reduction (Hackman \& Oldham, 1976). Hackman and Oldham's job characteristics theory (1974) tests the objective features of high-value work that improves employee well-being, motivation, and output. In addition, the model was built to characterize employee motivational features before job design and to recognize and calculate employee growth intensity (Hackman \&Oldham, 1974).

Richard Hackman's and Greg Oldham's (1980) work characteristics model comprises of five elements. Skill identity is the degree to which a job needs a variety of tasks, including the skills and talents of the employee (Ali et al., 2014). Job identity permits a worker to perform all necessary tasks from start to end. Furthermore, the worker's feeling that it benefits their firm is known as job significance (Hackman $\&$ Oldham, 1976). When the work allows the individual the right to use his authority during decision making, it is autonomy (Buys et al., 2007). When workers are told about their work performance directly and clearly, it is known as job feedback (Hunter, 2006).

\section{Job Satisfaction}

Employment satisfaction was often described as the pleasant emotional state of assessing one's job or job experiences, which is prompted by the feeling that one's employment fulfils one's core work values, given that these values are compatible with one's needs (Rai \& Maheshwari, 2020). Dissatisfaction happens when these values are not satisfied. Work satisfaction includes different characteristics; work satisfaction, salary, appreciation, supervisor-employee relationship and opportunity to achieve growth (Noe, 1985). Betts (2000) described job satisfaction as employee perception, defining the degree of satisfaction based on emotional needs.

\section{Growth Need Strength}

Hackman \& Oldham (1976) opined that strength for growth refers to the desire of a person to be challenged and to grow in a job. People with high growth needs would react favorably to jobs that provide opportunities for professional development (Hidayah, Nadhir, \& Puteh, 2017). On the other hand, people with less growth needs do not understand and appreciate the professional development opportunities (Lawrence, 2001). The strength needed for growth is how much individuals want to improve and generally do it (Saud, 2020). Psychologists who emphasize human potential contend that everyone has a minimum spark for personal growth and development (Sarkawi, Jaafar, Shamsuddin, \& Rahim, 2017).

\section{Relationship between Job Characteristics and Job Satisfaction}

Job satisfaction derives from the understanding of the working atmosphere such as supervisors, management policies, working conditions, and allowances (Fauzan, 2020). When the growth needs of the employees were high, the correlation between work characteristics and job satisfaction was strongly positive (Rai \& Maheshwari, 2020). The study revealed that workers are happy when they believe that their work is important (Obodo, Okonkwo, \& Aboh, 2019). Job satisfaction describes the worker's contentment with his job and research posits that each of the five work attributes has been positive for work satisfaction (Sarkawi et al., 2017). A research by Andrew, Haris, Zakariah, \& Athirah (2016) postulated the effect on job satisfaction from work characteristics.

An employee is contented with his job if his income is sufficient, his task is appealing, working conditions are good and the work inspires his supervisors (Aloysius, 2013). It is important to minimize 
the factors that can reduce employee satisfaction (Raddaha et al., 2012). Based on the meta-analysis, it appears that shifts in employment have an impact on the connection between job qualities and wellbeing (Humphrey, Nahrgang \& Morgeson, 2007).

Luthans (2006) states five factors influence the satisfaction of workers, specifically supervisors, salaries, opportunities to grow, and coworkers. The job model postulates that if all the elements are present at a job, the employee is more likely to be highly motivated, satisfied, rejuvenated with low absenteeism (Balkin, \& Cardy, 2005). The definition of work characteristics was also viewed as an interpretation of employee satisfaction (Glisson \& Durick 1988). Therefore, the following hypotheses are generated to analyze the relationship:

$\mathbf{H}_{\mathbf{1}}$ : Job Characteristics positively influence the job satisfaction of production workers of garments industry.

\section{Growth Need Intent as a Moderator between Job Characteristics and Job Satisfaction}

Growth need intent can be characterized as the strength of the personal achievement, learning, and development need of an individual. It has been described as a significant moderator on relationships between core jobs features and psychological states results (Saud, 2020). Psychologists who highlight individual development contend that everyone has at least a spark in him of personal growth and development (Senen, Masharyono, \& Edisa, 2020).

Hackman and Oldham (1975) also maintain out that people with a low personal development need do not understand and acknowledge the possibilities available in the work (Sarkawi et al., 2017). They agree that those with high growth intent will react more favourably to jobs that are high in their core employment dimensions, as they provide opportunities for improvement.

In his research, Graen and Others (1986) found that employee growth need intent as a moderator between opportunities for growth and productivity. Growth intent means the desire of a person to grow in the job, to improve his skills and abilities and improved performance (Hackman and Oldham, 1980, p.85). The connections between job and result are determined by the growing need of the employee's need for self-actualization and self-esteem (Hackman \& Oldham, 1980). Therefore, the following hypothesis is suggested;

$\mathbf{H}_{2}$ : The relationship between job characteristics and satisfaction is positively moderated by the growth need intent of production workers in garments industry.

\section{Research Framework}

This section presents the conceptual and theoretical framework of the research.

\section{Conceptual Framework}

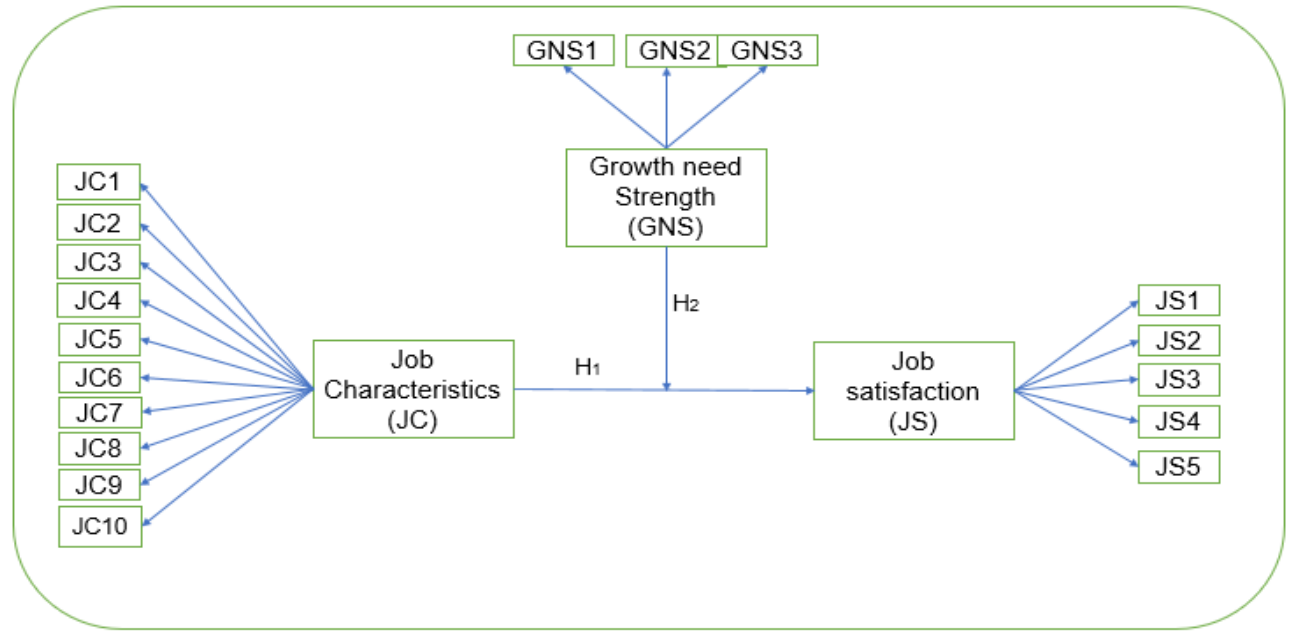


Figure 1 Conceptual Model

Figure 1 presents the conceptual framework wherein job characteristics are regarded as an independent variable and job satisfaction is assumed to be a dependent variable. The moderator that affects the relationship between core job characteristics and job satisfaction is the growth need intent of workers.

\section{Theoretical Framework}

Job characteristics are called theories of job design designed by (Turner \& Lawrence, 1965). The theory of job characteristics explains the individuals' work responses and their relationship with job features. The theory specifies the job state under which individuals are supposed to flourish in their work. The theory emphasizes that one of the most important outcomes is job satisfaction which gives quality work, effective performance, low absenteeism, and more revenue (Hackman \& Oldham, 1980).

\section{Research Methodology}

This section describes the research methodology in detail.

\section{Research Design}

The research was cross-sectional and used a deductive method. The self-administered questionnaire was used to gather data from workers working in the textile \& garments industry and the analysis unit was individual employees. The participants were production workers from different factories of garments industry in Lahore, Pakistan. A simple random sampling method is employed in this research. Data is collected from factory production workers by survey using a 7-point Likert scale questionnaire and analyzed using the PLS Smart (Ringle, Wende and Becker, 2015).

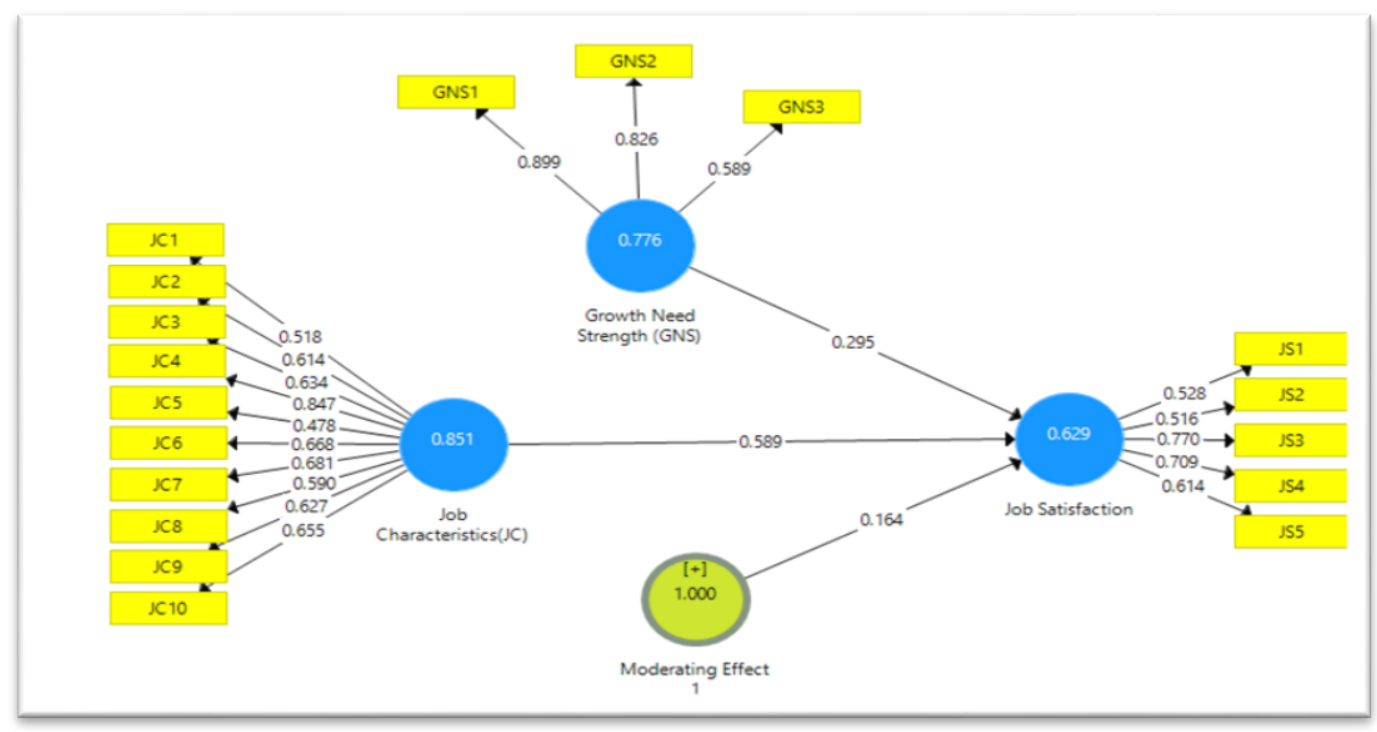

\section{Questionnaire Development}

Formerly established 18 items scale was used to assess work characteristics, job satisfaction, and growth need strength Likert scale has 7 points, ranging from strong disagreement to strong agreement. This research assessed job characteristics using a scale developed by Idaszak and Drasgow (1987) based on Oldham and Hackman's (1984) Job Diagnostic model. Growth needs strength and job satisfaction can be calculated by the Hackman - Oldham scale (1975). This measure was frequently employed in studies looking at the relationship between employment qualities and various results (Aloysius, 2011, Guise, 1988). 
Figure 2: Results Of Model Using Partial Least Squares

Assuming an accurate estimate of sample size, the ratio should not be less than 1:5. (Hair, Black, Babin \& Anderson, 2010). In this research, three latent variables were used and, according to the rule of thumb, the minimum sample requirement was 90 , depending on the item. Thus, based on this number, 125 questionnaires were distributed, of which $119(95.2 \%)$ of the total responses received were considered to be good for the generalization of the result.

\section{Results and Analysis}

The questionnaire was tested with ten possible applicants to ensure its clarity before being administered to the proposed audience. Cronbach alpha is used to check the internal consistency of the model. Figure 2 presents the result of the model using partial least squares. Table 1 displays the Cronbach alpha value from the analysis. The literature proposes 0.6 as the acceptable value for Cronbach Alpha (Taber, 2018), which illustrates that the instrument used in this research is reliable and fit for analysis.

Table 1: Value of Cronbach Alpha

\begin{tabular}{|l|l|}
\hline & Cronbach's Alpha \\
\hline Growth Need Strength (GNS) & $\mathbf{0 . 6 8 3}$ \\
\hline Job Characteristics (JC) & $\mathbf{0 . 8 3 5}$ \\
\hline Job Satisfaction & $\mathbf{0 . 6 1 9}$ \\
\hline
\end{tabular}

The goodness-of-fit test is checked for an outer and inner model. It is used to prove the acceptance of goodness-of-fit for the outer model and inner model (Hair et al., 2014, p. 186).

\section{Goodness-of-fit test for outer model}

The convergent validity of the external model is assessed using a AVE rate and factor loading rate estimation of Tables 2 and 3.

Table 2: Factor Loading for Outer Model

\begin{tabular}{|c|c|c|c|c|}
\hline & $\begin{array}{l}\text { Growth Need } \\
\text { Strength } \\
\text { (GNS) }\end{array}$ & $\begin{array}{l}\text { Job } \\
\text { Characteristics } \\
\text { (JC) }\end{array}$ & $\begin{array}{l}\text { Job } \\
\text { Satisfaction }\end{array}$ & $\begin{array}{l}\text { Moderating } \\
\text { Effect } 1\end{array}$ \\
\hline GNS1 & 0.899 & & & \\
\hline GNS2 & 0.826 & & & \\
\hline GNS3 & 0.589 & & & \\
\hline JC1 & & 0.518 & & \\
\hline JC10 & & 0.655 & & \\
\hline JC2 & & 0.614 & & \\
\hline JC3 & & 0.634 & & \\
\hline JC4 & & 0.847 & & \\
\hline JC5 & & 0.478 & & \\
\hline JC6 & & 0.668 & & \\
\hline JC7 & & 0.681 & & \\
\hline JC8 & & 0.590 & & \\
\hline JC9 & & 0.627 & & \\
\hline JS1 & & & 0.528 & \\
\hline JS2 & & & 0.516 & \\
\hline JS3 & & & 0.770 & \\
\hline JS4 & & & 0.709 & \\
\hline JS5 & & & 0.614 & \\
\hline
\end{tabular}




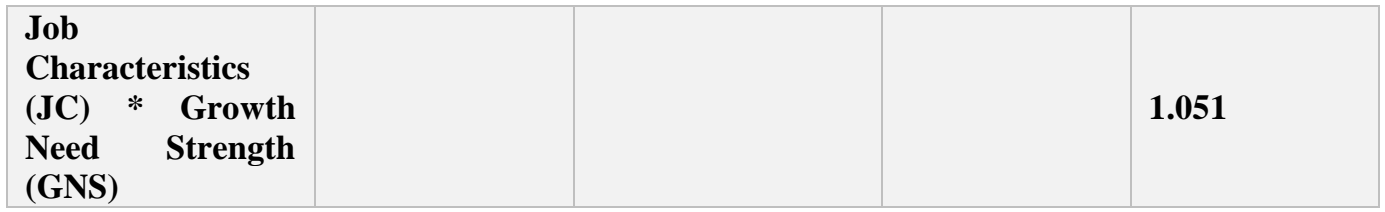

Source: Result with Smart PLS.

All of the indicators in Table 2 appear to be correct when it comes to determining convergent validity. AVE rates of all latent variables exceed 0.5, which indicates that all of these variables' hypotheses are accurate in relation to research methodology.

Table 3: AVE for outer Model

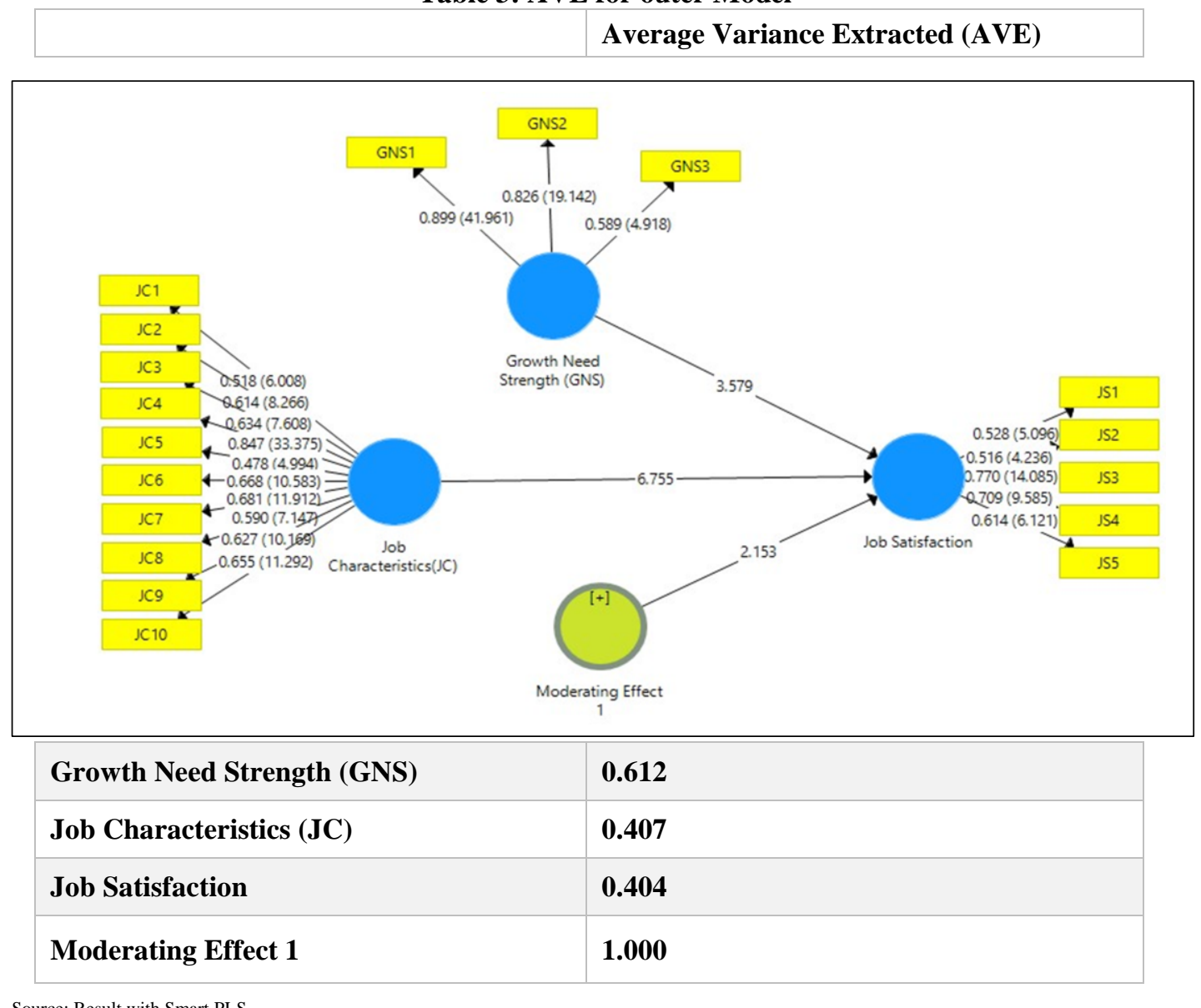

Variables closely linked are tested using convergent validity methodology. The average AVE as shown in Table 3 measures convergent validity. If AVE is less than 0.5, but composite reliability is higher than 0.6 , the convergent validity of the construct is still adequate (Fornell \& Larcker, 1981).

Figure 3 Result of the model using bootstrap

\section{Reliability test for outer model}

An outer model can be verified by the total reliability in each latent variable. The effects of the research on reliability of outer model are seen in Table 4.

Table 4: Outer Model Composite Reliability

\begin{tabular}{|l|l|}
\hline Variable & Composite Reliability \\
\hline Growth Need Strength (GNS) & 0.822 \\
\hline Job Characteristics (JC) & 0.871 \\
\hline
\end{tabular}




\begin{tabular}{|l|l|}
\hline Job Satisfaction & 0.767 \\
\hline Moderating Effect 1 & 1.000 \\
\hline
\end{tabular}

Source: Result with Smart PLS

\section{Inner model Goodness-of-fit test}

The Inner Model Goodness-of-Fit test is based on the $\mathrm{R}^{2}$ value. Table 5 shows that JC and even GNS moderation can account for 58.7 percent of the JS variance, with the remaining 41.3 percent explained by a variety of other variables. There is a good chance that the inner model is suitable for hypothesis testing now that the $\mathrm{R}^{2}$ criterion has been met.

Table 5: $\mathbf{R}^{2}$ Value for Inner Model

\begin{tabular}{|l|l|}
\hline & R Square \\
\hline Job Satisfaction (JS) & 0.587 \\
\hline
\end{tabular}

\section{Hypothesis test}

Hypotheses are checked by the processing values obtained from the bootstrapping test (figure 3 ). The test was used to determine the acceptance and rejection of hypotheses based on data collected from the research. Table 6 is displaying the results of hypotheses determining the level of hypotheses by testing and seeing the value of path coefficient, t-tests.

Table 6: Hypotheses Testing

\begin{tabular}{|c|c|c|c|c|c|c|}
\hline $\mathbf{S N}$ & Hypothesis & Suggested & $\begin{array}{c}\text { Path } \\
\text { Coefficient }\end{array}$ & $\begin{array}{c}\text { T- } \\
\text { Value }\end{array}$ & Significant & Confirmed \\
\hline H1 & $\begin{array}{l}\text { Job Characteristics } \\
\text { positively influence } \\
\text { the job satisfaction } \\
\text { of production } \\
\text { workers of the } \\
\text { garment industry. }\end{array}$ & + & 0.589 & 6.755 & $* * *$ & Yes \\
\hline H2 & $\begin{array}{l}\text { The relationship } \\
\text { between job } \\
\text { characteristics and } \\
\text { satisfaction is } \\
\text { positively } \\
\text { moderated by the } \\
\text { growth need } \\
\text { strength of } \\
\text { production workers } \\
\text { of the garment } \\
\text { industry. }\end{array}$ & + & 0.164 & 2.153 & $* *$ & Yes \\
\hline & \multicolumn{6}{|c|}{$\begin{array}{c}* \text { Significance at } 10 \%(1.645) p<0.10 \\
* * \text { Significance at } 5 \%(1.96)-p<0.05 \\
* * * \text { Significance at } 1 \%(2.576) p<0.01\end{array}$} \\
\hline
\end{tabular}

As from table 6, the outcomes of the hypotheses are determined by considering the results of the T-tests, the path coefficients, and the significance levels. All hypotheses show a positive association with each other and significant varies at each association.

\section{Discussion}

The possible applicability of the Job Characteristics Model to manufacturing industries in the Pakistani context indicates that the model is not entirely unrelated to the nature of manufacturing work in the region. The model has proven useful in defining basic facts about different kinds of work. However, in 
some of the factories, the model falls short. These shortcomings cannot completely negate the model in the Pakistani context. It just means that the policy system has to be changed to fit the idea into the industry. Policy suggestions should also be made to resolve these areas of deficiencies of the Hackman and Oldham Job Characteristics Models.

The research reveals that workers in the textile \& garments industry are satisfied with the identification of the task, the value of the task, the feedback for the activities, but are not satisfied with the range of autonomy and abilities. Employees in the textile and apparel industries have limited options when it comes to scheduling their time and determining how their work will be completed. The apparel industry's autocratic leadership affects employee productivity, commitment to goal fulfilment, job satisfaction, loyalty, and mental well-being. The research explains that it can be said that the implementation of skill varieties is missing for workers in the textile \& garments field. This means that the rotation of jobs is not completed for employees. So, the different abilities, strengths, potentialities of the workers are overlooked here, and there is no opportunity for growth. This practice in the textile \& garments industry reduces the chances of employees improving their careers and which makes them frustrated with their tasks. As a consequence, the productivity of workers, enthusiasm, and worker's morale is decreased.

Autonomy at work and facilities for the use of a range of skills by workers may be an important factor in the motivation and job satisfaction of workers. Organizations are also in charge of creating jobs and must devote enough resources to this task. Both variables are shown to be positively linked and the findings suggest that the work characteristics and job satisfaction are important to each other, but the job description model is not followed and completely applied to produce the desired results. Growth has also been shown to have a positive effect on the relationship, but this aspect is not used to the desired degree in some of the factories. Training \& development is a mechanism in which the skills of workers have been developed and are beneficial to the growth of workers, but this aspect is not utilized to the degree desired.

\section{Conclusion}

This study's findings suggest that job factors matter a lot when it comes to identifying differences and similarities among employees. The findings of this research showed that the job characteristics of employees had a significant relationship with their job satisfaction. Most employees do not understand work satisfaction and characteristics. It has been clear from the research that most of the workers with less education are satisfied with their tasks and don't need any variety because assembly-line efficiency means profit and efficiency comes from working on the same task. Workers having some qualification and urge to grow wants variety in their task to upgrade their skills and career. Some of the female workers have no concern with job features, they are satisfied if the working environment is suitable for them.

It has been observed that the majority of employees are not happy with their salaries, incentive package, and other services. According to their thinking, wage and incentive packages would increase work satisfaction. In the data analysis, we discovered that despite not knowing about employment aspects, employees expect a variety of task fulfilment, autonomy, and variety at work, as well as feedback from their managers. These factors can have a good impact on employee happiness and productivity, as well as boost employee confidence and devotion to the company's goals. The research reveals that employees are happy with their job identity and job work satisfaction. They are dissatisfied with job variety and their less freedom. It's heartening to see the contributions made by researchers in the realm of organisational motivation and job qualities, but it is worth noting that these ideas should be adapted to the needs of local workers organizations.

\section{Practical Implications}

Employee work satisfaction was found to be positively impacted by the basic job qualities of task 
variety, freedom, feedback, job involvement, and importance. HR managers can bring a wide range of variety by improving their skills. If the worker is familiar with various skills and methods his job can be changed. Skills can be improved by organizing training, workshops, etc. Employees must learn skills to develop his/her career. Managers should take into consideration and design adequate training for employees. The job identity is also increased by enhancing the skills of staff by training on latest machines and inclusion of additional duties or the upgrading of their tasks. Given the positive impact of task significance on job satisfaction, practitioners should concentrate on crafting jobs with high task importance. The focus of practitioners should be on delivering timely feedback to employees to increase productivity; achieve targets on time; minimize stress and better performance. Thus, in practice, changing the features of work can improve employment. and increasing employees' enthusiasm and satisfaction.

\section{Significance \& Recommendation}

Research into the impact of growth requires a stronger relationship between work characteristics and job satisfaction in the ready-made garment industry to fill a void that researchers have not filled. This paper represents a useful resource for practitioners and managers responsible for job responsibilities implementation because it demonstrates how they can get benefits from the new strategy and sustain the culture required to operate their processes. From a managerial point of view, the results connect theory to the model. Since the findings suggest that job characteristics tend to boost satisfaction, performance, and productivity. It is also suggested that HR managers adapt the strategy to enrich jobs by making improvements in job characteristics to further enhance the level of satisfaction and motivation of employees.

\section{References}

Ahmad, Z. (2012). Research Report on Pakistan's Textile Industry Analysis. SSRN Electronic Journal.

Aloysius, S. M. C. M. (2013). The Relationship between Perceived Job Characteristics and Job Satisfaction Among Bank Employees. SSRN Electronic Journal, (May).

Brief, A. P., \& Weiss, H. M. (2017). Organizational Behaviour: Affect in the Workplace. Annual. Rev. Psychol, (February 2002), 279-307.

Farooqui, M. R., \& Ahmed, M. (2013). Why Workers Switch Industry? The Case of Textile Industry of Pakistan. Asian Journal of Business Management, 5(1), 130-139.

Fauzan, R. (2020). Mediating effect of job satisfaction and organizational commitment in the influence of job characteristics towards performance. Journal of Critical Reviews, 7(13), 744-754.

Fornell, C., \& Larcker, D. F. (1981). Evaluating Structural Equation Models with Unobservable Variables and Measurement Error. Journal of Marketing Research, 18(1), 39.

Hackman, J. R., and Oldham, G. R. (1974). The Job Diagnostic Survey: An Instrument for the Diagnosis of Jobs and the Evaluation of Job Redesign Projects. Report No. 4, Yale University, Department of Administration Science, New Haven, CT., (1).

Hackman, J. R., \& Oldham, G. R. (1976). Motivation through the design of work: the test of a theory. Organizational Behaviour and Human Performance, 16(2), 250-279.

Hidayah, N., Nadhir, M., \& Puteh, F. (2017). Impact Assessment of Job Characteristics Model on Employee Engagement. E-Academia Journal, 6(1), 2289-6589.

Idaszak, J. R., \& Drasgow, F. (1987). A Revision of the Job Diagnostic Survey: Elimination of a Measurement Artifact. Journal of Applied Psychology, 72(1), 69-74. https://doi.org/10.1037/0021-9010.72.1.69

Kirmeyer, S. L. (2011). Perceived Job Autonomy in the Manufacturing Sector: Effects of Unions, Gender, and Substantive Complexity Author (s): Sandra L. Kirmeyer and Arie Shirom Source: The Academy of Management Journal, Vol. 29, No. 4 (Dec. 1986), pp. 832-840 Pub. Management, 29(4), 832-840.

Lawler, E. E., \& Hall, D. T. (1970). Relationship of job characteristics to job involvement, satisfaction, and intrinsic motivation. Journal of Applied Psychology, 54(4), 305-312.

https://doi.org/10.1037/h0029692 
Lawrence, R. M. (2001). The application of Hackman and Oldham's job characteristic model to perceptions community music school faculty have towards their job (J. R. Hackman, G. R. Oldham). Dissertation Abstracts International Section A: Humanities and Social Sciences, (August), I-167.

Loher, B. T., Noe, R. A., Moeller, N. L., \& Fitzgerald, M. P. (1985). A Meta-Analysis of the Relation of Job Characteristics to Job Satisfaction. Journal of Applied Psychology, 70(2), 280-289. https://doi.org/10.1037/0021-9010.70.2.280

Morgeson, F. P. H. (2006). The Work Design Questionnaire (WDQ): Journal of Applied Psychology, (6), 1321-1339.

Muku, A. Z. A. (2013). Job Characteristics Model of Hackman and Oldham in Garment Sector in Bangladesh: A Case Research in Savar Area in Dhaka District. International Journal of Economics, Finance and Management Sciences, 1(4), 188.

https://doi.org/10.11648/j.ijefm.20130104.12

Noe, R. A. (1985). A Meta-Analysis of the Relation of Job Characteristics to Job Satisfaction Article. Journal of Applied Psychology. https://doi.org/10.1037/0021-9010.70.2.280

Obodo, P. A., Okonkwo, E. A., \& Aboh, U. J. (2019). Job Characteristics and Job Satisfaction among Police Officers in Enugu Urban. Practicum Psychologia, 9(1), 139-157. Retrieved from http://journals.aphriapub.com/index.php.pp

Oldham, G. R. (1976). Job Characteristics and Internal Motivation: The Moderating Effect of Interpersonal and Individual Variables. Human Relations, 29(6), 559-569. https://doi.org/10.1177/001872677602900605

Rai, A., \& Maheshwari, S. (2020). Exploring the mediating role of work engagement between the linkages of job characteristics with organizational engagement and job satisfaction. Management Research Review, 44(1), 133-157. https://doi.org/10.1108/MRR-10-2019-0442

Raziq, A., \& Maulabakhsh, R. (2015). Impact of Working Environment on Job Satisfaction. Procedia Economics and Finance, 23(October 2014), 717-725. https://doi.org/10.1016/s22125671(15)00524-9

Ringle, C. M., Wende, S., and Becker, J.-M. (2015). PLS Algorithm | SmartPLS. Retrieved September 3, 2020, from https://www.smartpls.com/documentation/algorithms-and-techniques/pls

Saheed, O. (2018). The Applicability of the Hackman and Oldham's Job Characteristics Model to Assembly Line Manufacturing Organizations in Nigeria. UNIUYO Journal of Humanities (UUJH), 22(May), 277-292.

Sarkawi, M. N., Jaafar, A. R., Shamsuddin, J., \& Rahim, N. F. A. (2017). Impact of growth needs strength on the relationship between career salience and job satisfaction. International Journal of Economic Research, 14(16), 619-627.

Saud, T. R. (2020). The Effect of Job Characteristics on Organizational Commitment: The Role of Growth Need Strength in Nepali IT Companies. Journal of Business and Management Research, 3(1-2), 39-56. https://doi.org/10.3126/jbmr.v3i1.31973

Senen, S., Masharyono, M., \& Edisa, N. (2020). The Effect of Job Characteristics to Employee's Performance: A Case Research on Employees at Interior Industry. atlantis-press.com. Retrieved from https://www.atlantis-press.com/proceedings/gcbme-18/125933677

Taber, K. S. (2018). The Use of Cronbach's Alpha When Developing and Reporting Research Instruments in Science Education. Research in Science Education, 48(6), 1273-1296. https://doi.org/10.1007/s11165-016-9602-2 